\title{
PENGARUH JENIS MEDIA TANAM TERHADAP PERTUMBUHAN BIBIT SALAK (Salacca edulis Reinw)
}

\author{
Ajang Maruapey \\ Staf Pengajar FAPERTA Univ. Muhammadiyah Sorong, $\boldsymbol{e}$-mail: -
}

\begin{abstract}
ABSTRAK
Penelitian ini dilaksanakan di Kampung Salak, Kelurahan Klawasi Distrik Sorong Barat Kota Sorong. Kegiatan ini dilaksanakan mula mei sampai dengan agustus 2011. Tujuan percobaan ini adalah untuk melihat pengaruh jenis media tanam terhadap pertumbuhan bibit tanaman salak.Pernelitian ini dilakukan dalam bentuk rancangan Rancangan Acak Kelompok (RAK) yang terdiri dari delapan perlakuan dan tiga ulangan, p3erlakuan yang dicobakan yadalah sbb; yakni tanah, tanah + pupuk kandang, tanah + bokashi, tanah + kascing, pasir + pupuk kandang, pasir + bokashi, pasir + kascing. Hasil penelitian menunjukkan bahwa bahwa Media tanam tanah + bokashi dapat memberikan pertumbuhan bibit tanaman salak yang terbaik pada perlakuan jumlah daun terbanyak (3,00 helai) dan panjang akar terbanyak $(25,43 \mathrm{~cm})$. . Media tanam pasir + kascing $\left(M_{8}\right)$ menghasilkan tanaman tertinggi $(34,91 \mathrm{~cm})$, Media tanah + pupuk kandang $\left(M_{2}\right)$ menghasilkan jumlah akar terbanyak $(9,78 \mathrm{~cm}$, sedangkan Media pasir + kascing $\left(M_{8}\right)$ menghasilkan jumlah akar paling sedikit $(5,89 \mathrm{~cm})$. bahwa media pasir + kascing $\left(M_{8}\right)$ menghasilkan bibit tanaman segar terberat $(11,04 \mathrm{~g} 5$. bahwa media pasir + kascing $\left(M_{8}\right)$ menghasilkan bibit tanaman segar terberat $(11,04 \mathrm{~g})$.
\end{abstract}

Kata Kunci: Bibit salak, jenis media tanam

\section{PENDAHULUAN}

Tanamanan salak merupakan salah satu komoditas yang menarik untuk dikembangkan sebagai komoditas yang dapat memenuhi kebutuhan dalam negeri maupun ekspor. Tanaman salak tidak hanya menguntungkan dari analisis usaha tani saja, tetapi juga dari sudut pemanfaatan lahan dan pengamanan lingkungan antara lain penanamannya dapat dicampur atau ditumpangsarikan dengan tanaman tahunan yang pohonnya tinggi seperti kelapa, petai, kemiri dan tanaman buah-buahan lainnya. Buah salak selain dapat dimakan langsung sebagai buah segar, juga dapat diawetkan atau diolah menjadi asinan yang dapat tahan disimpan dalam waktu yang agak lama. Kandungan zat gizi dalam 100 g bahan buah salak yang dapat dimakan segar adalah 77,0 kalori energi; 0,4 g protein; 20,9 g karbohidrat; $28 \mathrm{~g}$ kalsium; $18 \mathrm{mg}$ fosfor; 4,2 mg besi; 0 SI vitamin A; $0,04 \mathrm{mg}$ vitamin $\mathrm{B} ; 2 \mathrm{mg}$ vitamin C; dan 78,0 mg air. Disamping itu buah salak baik untuk diet karena tidak mengandung lemak

Di Kota Sorong penanaman tanaman ini masih bersifat sederhana yakni tanpa pemupukan, jarak tanam yang tidak teratur, tidak melakukan penjarangan tanaman dan penggunaan bibit yang berasal dari anakan yang tumbuh liar di atas permukaan tanah atau benih yang ditanam seadanya. Untuk penanaman jenis salak bermutu petani dapat menyiapkan pembibitan sendiri dan sekaligus menanam jenis salak yang memiliki sifat baik. Pembibitan adalah faktor yang penting diperhatikan karena pembibitan merupakan tahap awal dalam melakukan pengembangan tanaman dimana bibit yang ditanam akan sangat mempengaruhi pertumbuhan tanaman selanjutnya. Cara pemilihan biji salak bermutu dapat dilakukan dengan memilih biji yang berasal dari pohon induk yang telah diketahui sifat unggulnya. Biji yang dipilih berasal dari buah yang mengandung 3 biji. Buah yang demikian, akan menghasilkan $70 \%$ pohon salak betina dan $30 \%$ jantan

Salak dapat diperbanyak dengan cara pembiakan generatif yakni melalui biji, kelebihan dengan cara ini adalah lebih mudah dan murah Bibit yang dihasilkan lebih banyak, tanaman umumnya lebih sehat dan hidup lebih lama, benih lebih mudah disimpan dan dikirimkan, dan 
memungkinkan diadakan perbaikan-perbaikan sifat tanaman dengan persilangan buatan. Sedangkan kekurangan cara perbanyakan dengan biji yakni sifat tanaman induk belum tentu menurun kepada benih yang ditanam. Apalagi kalau biji yang diperoleh berasal dari persarian silang dengan tanaman yang sifatnya berbeda (Soetomo, 2001).

Pertumbuhan dan perkembangan bibit tanaman salak yang baik tidak lepas dari penggunaan media tanam yang baik. Media tanam memegang peranan penting agar didapatkan bibit yang baik, seragam dan kuat, sehingga akan dihasilkan pohon salak yang sehat dan akan menghasilkan produksi yang berkesinambungan. Media tanam sebagai tempat tumbuh bibit tanaman salak dapat berasal dari beragam bahan salah satu diantaranya adalah pupuk organik yang bersumber dari bahan-bahan organik.

Pupuk organik merupakan bahan yang dihasilkan dari pelapukan sisa-sisa tanaman, hewan dan manusia. Seperti halnya pupuk anorganik, jenis pupuk organik sangat beragam. Kalau jenis pupuk anorganik ditentukan oleh kadar haranya, maka jenis pupuk organik ditentukan oleh asal bahan terbentuknya, sehingga dikenal istilah pupuk kandang, pupuk hijau, kompos, bokashi, kascing dan lain-lain. Keuntungan penggunaan pupuk organik adalah memperbaiki struktur tanah, menaikkan daya serap tanah terhadap air, mempertahankan kondisi kehidupan di dalam tanah, dan sebagai sumber unsur hara bagi tanaman (Parnata,2005)

Berdasarkan hal tersebut maka perlu dilakukan percobaan mengenai pengaruh jenis media tanam untuk pertumbuhan bibit tanaman salak, selain itu melalui percobaan ini diharapkan dapat menjadi bahan pertimbangan di masa yang akan datang dalam upaya pengembangan tanaman salak oleh pihak pemerintah daerah dan instansi terkait untuk mengantisipasi permintaan pasar di kemudian hari, dan juga diharapkan hasil percobaan ini mampu menggugah motivasi masyarakat petani dalam membudidayakan tanaman salaknya.

\section{METODE PENELITIAN}

\subsection{Pelaksanaan Penelitian}

Penelitian ini dilaksanakan di Kampung Salak Kelurahan Klawasi Distrik Sorong Timur Kota Sorong yang berlangsung pada bulan April sampai Juni, 2011. dengan tujuan untuk melihat pengaruh jenis media tanam terhadap pertumbuhan bibit tanaman salak. Bahan-bahan yang digunakan adalah biji salak varietas Pondo, Polybag ukuiran $(15 \mathrm{~cm} \times 20 \mathrm{~cm})$, pasir, tanah, bokashi sekam, pupuk kandang sapi, kascing, label. Alat-alat yang digunakan adalah cangkul, sendok, timbangan, meteran, kamera tali rafia, Kamera dan alat tulis menulis.

Penelitian ini dilakukan dalam bentuk rancangan Acak Kelompok (RAK) yang terdiri dari delapan perlakuan dan tiga kali ulangan. Perlakuan yang dicobakan yaitu : $\mathrm{M}=$ Tanah, $\mathbf{M}_{2}=($ Tanah + Pupuk Kandang $), \mathbf{M}_{3}=($ Tanah + Bokashi), $\mathrm{M}_{4}=($ Tanah + Kascing $)$, $\mathrm{M}_{5}=($ Pasir $), \mathrm{M}_{6}=($ Pasir + Pupuk Kandang $)$, $\mathbf{M}_{7}=($ Pasir + Bokashi $), M_{8}=($ Pasir + Kascing $)$.

Sesuai dengan rancangan yang digunakan maka model matematikanya adalah sebagai berikut :

$$
\begin{aligned}
Y_{i j} & =\mu+\alpha_{i}+\beta_{j}+\varepsilon_{i j} \\
\text { Dimana }: & \text { Hasil Pengamatan } \\
\text { Yij }= & \text { Nilai Tengah Umum } \\
\mu= & \text { Pengaruh Perlakuan ke-i } \\
\alpha_{i}= & \text { Pengaruh Blok } \\
\beta_{j}= & \text { Pengaruh Galat Percobaan dari Perlakuan } \\
\varepsilon_{i j}= & \text { ke-i dan Pemupukan Ke }-\mathrm{j} .
\end{aligned}
$$

Setiap perlakuan diulang sebanyak tiga kali, sehingga keseluruhannya terdapat 26 kelompok perlakuan, setiap kelompok perlakuan terdiri dari tiga tanaman sehingga jumlah keseluruhan dalam kelompok perlakiuan adalah 72 bibit tanaman.

Prosedur Penelitian

\section{Persiapan media}

Media tanam yang akan digunakan terlebih dulu disiapkan, kemudian masing-masing media dicampur dengan perbandingan $1: 1$ untuk setiap perlakuan kecuali pasir dan tanah. Media yang telah tercampur, dimasukkan ke dalam polybag kemudian disiram air dan dibiarkan selama seminggu. Setelah itu siap untuk ditanami.

\section{Penyediaan benih}

Benih diambil dari buah salak yang sehat dan mengandung 3 biji, kemudian dicuci dengan air bersih sehingga tidak terdapat lagi daging buah yang tertinggal pada biji salak. Selanjutnya direndam dalam air selama $24 \mathrm{jam}$, setelah itu dicuci kembali kemudian benih langsung ditanam

\section{Penanaman}

Penanaman dilakukan dengan membuat lubang tanaman pada media yang telah dibasahi sebelumnya, kemudian diisi satu biji setiap polybag. Cara meletakkan biji dengan cara dibaringkan atau tertelungkup, dengan 
membenamkan $2 / 3$ biji sehingga sebagian masih terlihat.

\section{Pemeliharaan}

Pemeliharaan terdiri dari penyiraman dua kali sehari yakni pagi dan sore hari, penyiangan gulma dan penggemburan dengan menggunakan sendok.

\subsection{Variabel Pengamatan}

Komponen pertumbuhan yang diamati dalam penelitian ini adalah :

1. Tinggi tanaman $(\mathrm{cm})$, diukur setiap minggu mulai dari pangkal batang sampai ujung daun tertinggi. Pengukuran dimulai sejak biji berkecambah sampai minggu $12 \mathrm{mst}$. Pengolahan data diambil dari data terakhir pengamatan.

2. Jumlah daun (helai), dihitung setiap dua minggu dari jumlah daun yang terbentuk. Perhitungan dimulai sejak munculnya daun pertama sampai minggu mst. Pengolahan data diambil dari data terakhir pengamatan.

3. Panjang akar $(\mathrm{cm})$, diukur akar terpanjang mulai dari pangkal akar sampai ujung akar pada minggu $12 \mathrm{mst}$.
4. Jumlah akar, dihitung jumlah akar yang terbentuk pada minggu 12 diakhir percobaan.

5. Berat segar tanaman (g), ditimbang berat segar seluruh bagian tanaman pada minggu 12 diakhir percobaan

\subsection{Analisa Data}

Hasil Penelitian ini dianalisis dengan menggunakan analisis sidik ragam (Anova) sesuai dengan rancangan yang digunakan apabila berpengaruh nyata, maka akan dilanjutkan dengan Uji Jarak Beda Duncan (JBD) Pada taraf kepercayaan $0,05 \%$.

\section{HASIL DAN PEMBAHASAN \\ 3.1. Hasil \\ 3.1.1. Tinggi bibit tanaman}

Tinggi bibit tanaman salak dan sidik ragamnya disajikan pada Tabel Lampiran 1a dan 1b. Sidik ragam menunjukkan bahwa perlakuan media tanam berpengaruh sangat nyata terhadap tinggi bibit tanaman salak. Rata-rata tinggi bibit tanaman salak pada berbagai media tanam pada umur 12 minggu setelah tanam disajikan pada Tabel 1.

Tabel 1. Rata-rata Tinggi (cm) Bibit Tanaman Salak Pada Umur 12 Minggu Setelah Tanam

\begin{tabular}{|c|c|c|}
\hline Perlakuan & Rata-rata & NP JBD $(0,01)$ \\
\hline$M 8(P+K)$ & $34.91^{a}$ & 1.213 \\
\hline $\mathrm{M} 3(\mathrm{~T}+\mathrm{B})$ & $33.47^{b}$ & 1.273 \\
\hline$M 6(P+P k)$ & $33.13^{b}$ & 1.309 \\
\hline$M 7(P+B)$ & $32.96^{b}$ & 1.334 \\
\hline $\mathrm{M} 2(\mathrm{~T}+\mathrm{Pk})$ & $32.64^{b}$ & 1.350 \\
\hline $\mathrm{M} 4(\mathrm{~T}+\mathrm{K})$ & $32.60^{b}$ & 1.358 \\
\hline $\mathrm{M} 1(\mathrm{~T})$ & $30.68^{c}$ & 1.366 \\
\hline M5 (P) & $29.99 c$ & \\
\hline
\end{tabular}

Hasil Uji JBD pada Tabel 1 menunjukkan bahwa media pasir + kascing $\left(\mathrm{M}_{8}\right)$ menghasilkan tanaman tertinggi $(34,91 \mathrm{~cm})$ dan berbeda sangat nyata dengan perlakuan media tanam lainnya. Media pasir $\left(\mathrm{M}_{5}\right)$ menghasilkan tanaman terendah $(29,99 \mathrm{~cm})$.

\subsubsection{Jumlah daun}

Jumlah daun bibit tanaman salak dan sidik ragamnya disajikan pada Tabel Lampiran 2a dan 2b. Sidik ragam menunjukkan bahwa perlakuan media tanam berpengaruh sangat nyata terhadap jumlah daun bibit tanaman salak. Rata-rata jumlah daun bibit tanaman salak pada berbagai media tanam pada umur 12 minggu setelah tanam disajikan pada Tabel 2.

Hasil Uji JBD pada Tabel 2 menunjukkan bahwa media tanah + bokashi $\left(\mathrm{M}_{3}\right)$ menghasilkan jumlah daun terbanyak (3,00 helai) dan tidak berbeda nyata dengan media pasir + kascing $\left(\mathrm{M}_{8}\right)$, tetapi berbeda sangat nyata dengan perlakuan media tanam lainnya. Media tanah $\left(\mathrm{M}_{1}\right)$, tanah + kascing $\left(\mathrm{M}_{4}\right)$, pasir $\left(\mathrm{M}_{5}\right)$ dan pasir + bokashi $\left(\mathrm{M}_{7}\right)$ menghasilkan jumlah daun paling sedikit $(2,00$ helai) . 


\subsubsection{Panjang akar}

Panjang akar bibit tanaman salak dan sidik ragamnya disajikan pada Tabel Lampiran 3a dan 3b. Sidik ragam menunjukkan bahwa perlakuan media tanam berpengaruh sangat nyata terhadap panjang akar bibit tanaman salak. Rata-rata panjang akar bibit tanaman salak pada berbagai media tanam disajikan pada umur 12 minggu setelah tanam disajikan pada Tabel 3 .

Hasil Uji JBD pada Tabel 3 menunjukkan bahwa media tanah + bokashi $\left(\mathrm{M}_{3}\right)$ menghasilkan akar terpanjang $(25,43 \mathrm{~cm})$ dan tidak berbeda nyata dengan media tanah + pupuk kandang
$\left(\mathrm{M}_{2}\right)$, tetapi berbeda sangat nyata dengan perlakuan media tanam lainnya. Media tanah + Kascing (M4) menghasilkan akar terpendek $(14,90 \mathrm{~cm})$.

\subsubsection{Jumlah akar}

Jumlah akar bibit tanaman salak dan sidik ragamnya disajikan pada Tabel Lampiran 4a dan 4b. Sidik ragam menunjukkan bahwa perlakuan media tanam berpengaruh sangat nyata terhadap jumlah akar bibit tanaman salak. Rata-rata jumlah akar bibit tanaman salak pada berbagai media tanam disajikan pada umur 12 minggu setelah tanam disajikan pada Tabel 4.

Tabel 2. Rata-rata Jumlah Daun (helai) Bibit Tanaman Salak Pada Umur 12 Minggu Setelah Tanam

\begin{tabular}{ccc}
\hline Perlakuan & Rata-rata & NP JBD $(\mathbf{0 , 0 1})$ \\
\hline M3 $(\mathrm{T}+\mathrm{B})$ & $3.00^{\mathrm{a}}$ & 0.405 \\
$\mathrm{M} 8(\mathrm{P}+\mathrm{K})$ & $2.89^{\mathrm{a}}$ & 0.425 \\
$\mathrm{M} 2(\mathrm{~T}+\mathrm{Pk})$ & $2.33^{\mathrm{b}}$ & 0.437 \\
$\mathrm{M} 6(\mathrm{P}+\mathrm{Pk})$ & $2.22^{\mathrm{b}}$ & 0.445 \\
$\mathrm{M} 1(\mathrm{~T})$ & $2.00^{\mathrm{b}}$ & 0.450 \\
$\mathrm{M} 4(\mathrm{~T}+\mathrm{K})$ & $2.00^{\mathrm{b}}$ & 0.453 \\
$\mathrm{M} 5(\mathrm{P})$ & $2.00^{\mathrm{b}}$ & 0.456 \\
$\mathrm{M} 7(\mathrm{P}+\mathrm{B})$ & $2.00^{\mathrm{b}}$ & \\
\hline Keterangan : Angka-angka yang diikuti oleh huruf yang sama berarti tidak berbeda nyata pada taraf uji
\end{tabular}

Tabel 3. Rata-rata Panjang Akar (cm) Bibit Tanaman Salak Pada Umur 12 Minggu Setelah Tanam

\begin{tabular}{ccc}
\hline Perlakuan & Rata-rata & NP JBD $(\mathbf{0 , 0 1})$ \\
\hline M3 $(\mathrm{T}+\mathrm{B})$ & $25.43^{\mathrm{a}}$ & 1.051 \\
$\mathrm{M} 2(\mathrm{~T}+\mathrm{Pk})$ & $25.42^{\mathrm{a}}$ & 1.103 \\
M5 $(\mathrm{P})$ & $24.17^{\mathrm{b}}$ & 1.134 \\
M6 $(\mathrm{P}+\mathrm{Pk})$ & $24.09^{\mathrm{b}}$ & 1.155 \\
M8 $(\mathrm{P}+\mathrm{K})$ & $23.34^{\mathrm{b}}$ & 1.169 \\
M7 (P + B) & $16.26^{\mathrm{c}}$ & 1.176 \\
M1 (T) & $15.74^{\mathrm{cd}}$ & 1.182 \\
M4 (T+ K) & $14.90^{\mathrm{d}}$ & \\
\hline Keterangan : Angka-angka yang diikuti oleh huruf yang sama berarti tidak berbeda nyata pada taraf uji
\end{tabular}

Tabel 4. Rata-rata Jumlah Akar (lembar) Bibit Tanaman Salak Pada Umur 12 Minggu Setelah Tanam

\begin{tabular}{ccc}
\hline Perlakuan & Rata-rata & NP JBD $(\mathbf{0 , 0 1})$ \\
\hline M2 $(\mathrm{T}+\mathrm{Pk})$ & $9.78^{\mathrm{a}}$ & 1.205 \\
$\mathrm{M} 4(\mathrm{~T}+\mathrm{K})$ & $9.22^{\mathrm{a}}$ & 1.264 \\
$\mathrm{M} 3(\mathrm{~T}+\mathrm{B})$ & $9.00^{\mathrm{a}}$ & 1.300 \\
M1 $(\mathrm{T})$ & $7.78^{\mathrm{b}}$ & 1.324 \\
M6 $(\mathrm{P}+\mathrm{Pk})$ & $7.00^{\mathrm{bc}}$ & 1.340 \\
M7 (P + B) & $6.78^{\mathrm{bc}}$ & 1.348 \\
M5 (P) & $6.00^{\mathrm{c}}$ & 1.356 \\
M8 (P $+\mathrm{K})$ & $5.89^{\mathrm{c}}$ & \\
\hline Keterangan $:$ Angka-angka yang diikuti oleh huruf yang sama berarti tidak berbeda nyata pada taraf uji
\end{tabular}


Hasil Uji JBD pada Tabel 4 menunjukkan bahwa media tanah + pupuk kandang $\left(\mathrm{M}_{2}\right)$ menghasilkan jumlah akar terbanyak $(9,78 \mathrm{~cm})$ dan tidak berbeda nyata dengan media tanah + bokashi $\left(\mathrm{M}_{3}\right)$ dan tanah + kascing $\left(\mathrm{M}_{4}\right)$, tetapi berbeda sangat nyata dengan perlakuan media tanam lainnya. Media pasir + kascing $\left(\mathrm{M}_{8}\right)$ menghasilkan jumlah akar paling sedikit $(5,89 \mathrm{~cm})$.

\subsubsection{Berat bibit tanaman}

Berat segar bibit tanaman salak dan sidik ragamnya disajikan pada Tabel Lampiran 5a dan 5b. Sidik ragam menunjukkan bahwa masingmasing perlakuan media tanam berpengaruh sangat nyata terhadap berat segar bibit tanaman salak. Rata-rata berat segar bibit tanaman salak pada berbagai media tanam pada umur 12 minggu setelah tanam disajikan pada Tabel 5 .

Hasil Uji JBD pada Tabel 5 menunjukkan bahwa media pasir + kascing $\left(\mathrm{M}_{8}\right)$ menghasilkan bibit tanaman segar terberat $(11,04 \mathrm{~g})$ dan berbeda sangat nyata dengan perlakuan media tanam lainnya. Media tanah $\left(\mathbf{M}_{1}\right)$ menghasilkan bibit tanaman segar teringan $(7,61 \mathrm{~g})$.

Tabel 5. Rata-rata Berat Segar (g) Bibit Tanaman Salak Pada Umur 12 Minggu Setelah Tanam

\begin{tabular}{lcc}
\hline \multicolumn{1}{c}{ Perlakuan } & Rata-rata & NP JBD $(\mathbf{0 , 0 1})$ \\
\hline $\mathrm{M}_{8}(\mathrm{P}+\mathrm{K})$ & $11.04^{\mathrm{a}}$ & 0.837 \\
$\mathrm{M}_{3}(\mathrm{~T}+\mathrm{B})$ & $9.53^{\mathrm{b}}$ & 0.879 \\
$\mathrm{M}_{6}(\mathrm{P}+\mathrm{Pk})$ & $9.00^{\mathrm{bc}}$ & 0.904 \\
$\mathrm{M}_{7}(\mathrm{P}+\mathrm{B})$ & $8.77^{\mathrm{bc}}$ & 0.920 \\
$\mathrm{M}_{2}(\mathrm{~T}+\mathrm{Pk})$ & $8.71^{\mathrm{bc}}$ & 0.931 \\
$\mathrm{M}_{5}(\mathrm{P})$ & $8.63^{\mathrm{bc}}$ & 0.937 \\
$\mathrm{M}_{4}(\mathrm{~T}+\mathrm{K})$ & $8.18^{\mathrm{cd}}$ & 0.942 \\
$\mathrm{M}_{1}(\mathrm{~T})$ & $7.61^{\mathrm{d}}$ & \\
\hline Keterangan : Angka-angka yang diikuti oleh huruf yang sama berarti tidak berbeda nyata pada taraf uji \\
JBD 0,01
\end{tabular}

\subsection{Pembahasan}

Hasil sidik ragam terhadap seluruh parameter yang diamati menunjukkan bahwa perlakuan media tanam memberikan pengaruh yang nyata. Hal ini berarti terdapat perbedaan pengaruh dari berbagai media tanam yang diteliti.

Hasil analisa lanjut menunjukkan bahwa media pasir + kascing $\left(\mathbf{M}_{8}\right)$ menghasilkan tanaman tertinggi, dan berbeda sangat nyata dengan perlakuan media tanam lainnya. tanah + bokashi $\left(\mathrm{M}_{3}\right)$ menghasilkan jumlah daun terbanyak. dan tidak berbeda nyata dengan media pasir + kascing $\left(\mathrm{M}_{8}\right)$, tetapi berbeda sangat nyata dengan perlakuan media tanam lainnya. media tanah + bokashi $\left(\mathrm{M}_{3}\right)$ menghasilkan akar terpanjang. dan tidak berbeda nyata dengan media tanah + pupuk kandang $\left(\mathbf{M}_{2}\right)$, tetapi berbeda sangat nyata dengan perlakuan media tanam lainnya. media tanah + pupuk kandang $\left(\mathrm{M}_{2}\right)$ menghasilkan jumlah akar terbanyak. dan tidak berbeda nyata dengan media tanah + bokashi $\left(\mathrm{M}_{3}\right)$ dan tanah + kascing (M4), tetapi berbeda sangat nyata dengan perlakuan media tanam lainnya.dan media pasir + kascing $\left(\mathrm{M}_{8}\right)$ menghasilkan bibit tanaman segar terberat dan berbeda sangat nyata dengan perlakuan media tanam lainnya.
Media tanah + bokashi secara umum memberikan hasil terbaik pada jumlah daun dan panjang akar dimana pengaruh media tersebut disebabkan oleh bokashi, oleh bokashi sebagai fasilitas mikroorganisme (sumber energi) dapat melepaskan unsur hara ke dalam media tanah sehingga unsur tersebut dapat segera tersedia. Bokashi adalah bahan organik yang sudah difermentasikan. Proses fermentasi tersebut berlangsung dengan adanya mikroorganisme fakultatif (misalnya ragi) yang memfermentasi bahan organik kompleks menjadi senyawa organik sederhana yang dapat diserap langsung oleh tanaman.

Menurut Wididana dan Teruo (2003), mikroorganisme efektif atau yang lebih dikenal dengan $\mathrm{EM}_{4}$ adalah suatu kultur campuran yang mengandung berbagai mikroorganisme bermanfaat yang dapat digunakan sebagai sumber inokulum untuk meningkatkan keragaman mikroba. Hal ini tentu saja dapat meningkatkan proses fermentasi bahan organik dalam tanah, selain itu dapat memperbaiki kesehatan dan kualitas tanah dan pada gilirannya juga akan memperbaiki pertumbuhan serta jumlah dan mutu hasil tanaman. Aplikasi EM4 secara kontinyu pada konsentrasi yang tepat akan menjamin populasi mikroorganisme efektif dalam tanah. 
Pemberian Em4 yang diaplikasikan pada tanaman selain dapat memperbaiki sifat fisik, kimia dan biologi tanah, juga dapat memfermentasikan bahan organik tanah dan mempercepat proses dekomposisinya.

Selain itu bakteri fotosintetik yang dikandung oleh $\mathrm{EM}_{4}$ pada bokashi memiliki kemampuan untuk menfiksasi $\mathrm{N}$ yang sangat diperlukan oleh tanaman sebagai penyusun protein, protoplasma dan mendukung pertumbuhan vegetatif seperti jumlah daun dan proses perkembangan akar. Sarief (2006), menyatakan bahwa nitrogen merupakan bahan penyusun protein, protoplasma dan pembentuk bagian tanaman seperti batang dan daun yang merupakan tempat aktivitas fotosintesis yang menghasilkan asimilat untuk pertumbuhan cabang.

Media tanah + pupuk kandang secara umum memberikan hasil terbaik setelah media tanah + bokashi pada jumlah akar. Pupuk kandang sebagaimana halnya dengan pupukpupuk organik sebelumnya, umumnya mempunyai sifat-sifat yang sama seperti meningkatkan kesuburan tanah, sifat fisik tanah dan menambah kandungan bahan organik yang merupakan fasilitas yang baik bagi perkembangan akar yang menyebabkan perkembangan akar menjadi baik sehingga jumlah akar yang terbentuk lebih banyak pada bibit tanaman salak. Hal ini sejalan dengan pendapat Setyamidjaja (2006), bahwa pupuk kandang berfungsi menambah kandungan bahan organik, memperbaiki sifat fisik tanah, meningkatkan kesuburan tanah, memperbaiki kehidupan mikroorganisme, serta melindungi tanah terhadap erosi.

Pupuk kandang yang digunakan adalah pupuk kandang sapi yang tergolong sebagai pupuk dingin. Menurut Sutedjo dkk., (2001), pupuk kandang sapi tergolong pupuk dingin karena perubahan dari bahan yang terkandung dalam pupuk menjadi tersedia di dalam tanah berlangsung perlahan-lahan. Pupuk ini lambat menjadi matang dan lambat pula melepaskan unsur-unsur hara yang dikandungnya, sehingga ketersediaannya berlangsung secara berkesinambungan.

Media pasir + kascing memberikan hasil terbaik secara umum setelah media tanah + pupuk kandang pada tinggi tanman dan berat segar tanaman. Hasil ini mungkin disebabkan media kascing kaya akan kandungan hara sehingga dapat mensuplai kebutuhan pertumbuhan bibit tanaman salak. Kascing memegang peran penting dalam mendegradasikan bahan organik di dalam media tempat tumbuh sehingga unsur-unsur hara dalam keadaan tersedia bagi tanaman dan mudah diserap oleh akar yang pada akhirnya dapat ditranslokasikan ke seluruh tubuh tanaman. Parnata, (2005), menyatakan bahwa kascing mempunyai fungsi antara lain mendegradasi bahan organik dan meningkatkan laju siklus nutrisi, mentranslokasikan bahan organik ke dalam tanah, mengurangi pemadatan tanah, membuka lapisan top soil dan mendukung pertumbuhan akar tanaman. Hakim dkk., (2006), menambahkan bahwa kotoran cacing kaya akan unsur hara, karena itu cacing dapat memperkaya tanah dengan hara melalui kotorannya.

Media pasir merupakan partikel yang bersifat permeabel yakni sangat mudah dilalui oleh air dan udara bahkan unsur hara sehingga kekuatan untuk menyimpan air dan hara sangat kecil. Hal ini selanjutnya dapat mempengaruhi pembentukan organ vegetatif pada pertumbuhan bibit tanaman sehingga jumlah akar dan panjang akar yang terbentuk menunjukkan rata-rata yang lebih rendah.

Menurut Pairunang dkk., (2005), tanah-tanah berpasir harus seringkali mendapat tambahan air dan hara tanaman supaya produktif. Hal tersebut juga terjadi pada perlakuan media tanam pasir + pupuk kandang serta media tanam pasir + bokashi. Meskipun kekurangan fraksi liat pada pasir dapat ditingkatkan dengan penambahan bahan organik yang berasal dari pupuk kandang, kascing dan bokashi yang kaya akan bahan organik tetapi pengaruhnya masih lebih rendah dibandingkan dengan tanah yang memiliki struktur fisik lebih sesuai untuk pertumbuhan dan perkembangan bibit tanaman salak.

Penggunaan media tanam yang hanya berupa tanah tanpa ditambahkan unsur hara menyebabkan pertumbuhan dan perkembangan bibit tanaman salak tidak optimal. Umumnya unsur hara telah tersedia di dalam tanah, tetapi karena secara terus menerus diserap oleh tanaman maka jumlahnya akan berkurang. Menurut Hardjowigeno (2002), dengan adanya usaha pertanian yang dilakukan oleh manusia maka proses penghanyutan (erosi) dan pencucian zat hara yang hilang diperbesar. Selain itu unsurunsur hara yang hilang dari tanah pertanian bersama bagian-bagian tanaman yang dipanen manusia juga tidak sedikit. Hal ini menyebabkan daya dukung tanah terhadap tanaman menjadi berkurang. 
Tanah yang digunakan dalam percobaan ini berasal dari tanah perkebunan milik masyarakat setempat. Namun demikian, lain halnya dengan tanah yang telah ditambahkan dengan kascing yang berarti adanya upaya penambahan unsur hara pada tanah sehingga hasil yang diperoleh secara umum lebih besar dari media tanam yang hanya berupa tanah saja. Seperti halnya tanah, penggunaan media tanam pasir tanpa penambahan unsur hara sangat berpengaruh pada pertumbuhan tanaman.

Media pasir sangat mudah dilalui air dan udara (permeabel) sehingga daya simpannya terhadap air maupun unsur hara sangat rendah, sehingga tanaman yang tumbuh pada media tersebut tidak dapat mengalami pertumbuhan dan perkembangan yang optimal. Menurut Pairunang dkk., (2005) tanah dengan tekstur pasir mudah ditembus akar, mempunya kemampuan menyimpan air yang sangat rendah, kemampuan menyimpan hara tanaman yang sangat kecil.

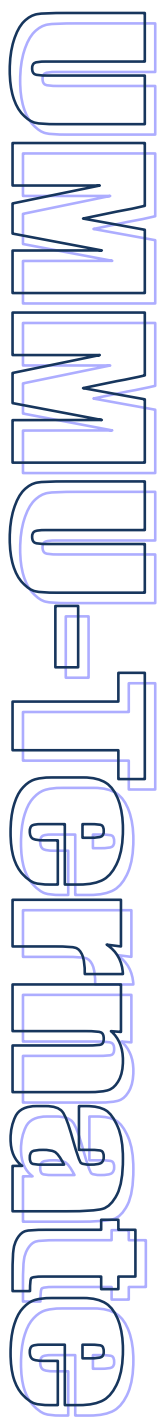

Hardjowigeno, S. 2002. Ilmu Tanah. Melton Putra. Jakarta. Jakarta. Microorganisme 4. Songgolangit Persada, Jakarta

\section{KESIMPULAN DAN SARAN}

\subsection{Kesimpulan}

Berdasarkan hasil penelitian yang dilakukan, maka dapat diambil kesimpulan bahwa :

1. Media tanam tanah dan bokashi dapat memberikan pertumbuhan bibit tanaman salak yang terbaik pada perlakuan jumlah daun terbanyak $(3,00$ helai) dan panjang akar terbanyak $(25,43 \mathrm{~cm})$,

2. Media tanah dan pupuk kandang $\left(\mathbf{M}_{2}\right)$ menghasilkan jumlah akar terbanyak $(9,78$ $\mathrm{cm}$, sedangkan Media pasir + kascing $\left(\mathrm{M}_{8}\right)$ menghasilkan jumlah akar paling sedikit $(5,89 \mathrm{~cm})$.

3. Bahwa media pasir + kascing $\left(\mathrm{M}_{8}\right)$ menghasilkan bibit tanaman segar terberat (11,04 g5. bahwa media pasir + kascing $\left(\mathrm{M}_{8}\right)$ menghasilkan bibit tanaman segar terberat $(11,04 \mathrm{~g})$

\subsection{Saran}

Pada media tanam yang terbaik sebaiknya digunakan untuk penelitian-pnelitian sekanjutnya terhadap pembibitan tanaman salak.

\section{DAFTAR PUSTAKA}

Hakim, N., Yusuf Nyakpa, A.M. Lubis, Sutopo Ghani, Rusdi saul, M. Amin Diha, Go Ban Hong, H. Bailey. 2006. Dasar-dasar Ilmu Tanah. Universitas Lampung, Lampung.

Pairunan, AK., Arifin., B.Ibrahim., H. Asmadi., R Tangkaisari., Solo S.R Samosir. 2005. Dasar-Dasar Ilmu Tanah. Badan Kerjasama Perguruan Tinggi Negeri Indonesia Indonesia Timur.

Parnata, A. S, 2005. Pupuk Organik Cair Aplikasi dan Manfaatnya. Agromedia

Salam, H.S. 2007. Pengolahan Sampah Menjadi Kompos dengan Bantuan Cacing Tanah. Walhi,

Sarief, S. 2006. Kesuburan dan Pemupukan Tanah Pertanian. Pustaka Buana, Bandung.

Setyamidjaja, D. 2006. Pupuk dan Pemupukan. Edisi revisi CV Simplekx, Jakarta.

Sutedjo, M. M. Kartasapoetra, Sastroatmojo. 2001. Mikrobiologi Tanah. Rineka Cipta, Jakarta. Wididana, G.N., dan Teruo, H. 2003. Penuntun Bercocok Tanam Padi dengan Teknologi Efective 